\title{
The Effect of Kinesio Tape Application on Functional Performance in Surgeons Who have Musculo- Skeletal Pain after Performing Surgery
}

\author{
Cerrablarda Ameliyat Sonrası Gelişen Kas İskelet Sistemi Ağrıları \\ Üzerinde Kinesio Bantlama Tekniğinin Fonksiyonel Performansa Etkisi
}

\author{
Nihan KARATAS ${ }^{1}$, Seda BICICI ${ }^{2}$, Gul BALTACI ${ }^{2}$, Hakan CANER $^{3}$ \\ ${ }^{1}$ Gazi University, Faculty of Health Sciences, Department of Physiotherapy Rehabilitation, Ankara, Turkey \\ ${ }^{2}$ Hacettepe University, Faculty of Health Sciences, Department of Physiotherapy and Rehabilitation, Ankara, Turkey \\ ${ }^{3}$ Baskent University, Faculty of Medicine, Department of Neuorosurgery, Ankara, Turkey
}

Correspondence address: Nihan KARATAS / E-mail: nihankaratas86@hotmail.com

\begin{abstract}
AIM: Surgeons make up a unique group that is at risk for developing work-related musculoskeletal symptoms. The purpose of this study was to evaluate the effect of Kinesiotape technique on pain and functional performance in surgeons who have musculoskeletal system pain after performing surgery.

MATERIAL and METHODS: 32 surgeons between the ages of 27 and 44 yrs working in a university hospital were included. The Visual Analog Scale (VAS) was used to evaluate the surgeons' neck and low back pain and the Oswestry Low Back and Neck Disability Indexes were used to determine the impact of pain on daily living activities. First, surgeons were evaluated without Kinesiotape application, then evaluated again on the first day and fourth day of Kinesiotape application.

RESULTS: The results showed that surgeons had a significant reduction in neck and low back pain $(p<0.05)$. There were improvements in both Oswestry Low Back Disability Index and Neck Disability Index scores when compared with their initial status ( $p<0.05)$. After Kinesiotape application, neck and low back range of motions' scores showed an increase $(p<0.05)$.

CONCLUSION: Findings demonstrated that Kinesio taping would be an effective method for reducing neck and low back pain and improving functional performance.
\end{abstract}

KEYWORDS: Surgeons, Musculoskeletal pain, Kinesiotaping, Performance

ÖZ

AMAÇ: Bu çalışmanın amacı, ameliyatlardan sonra kas iskelet sistemi ağrısı olan cerrahlarda, yaşam kalitesi ile ilişkili fonksiyonel performans ve ağrı üzerinde Kinesio bantlamanın etkisini değerlendirmektir.

YÖNTEM ve GEREÇ: 27-44 yaşları arasında değişen 32 cerrah çalışmaya katılmıştır. Cerrahlar bel ve boyun ağrısı değerlendirmesi için Görsel Analog Skalası ile bel ve boyun ağrısının cerrahın günlük yaşantısını ne derecede etkilediğini görmek için ise Oswestry Bel ve Boyun Özür Skalaları ile değerlendirilmişlerdir. Cerrahların bel ve boyun eklem hareket açıklıkları ise gonyometre kullanılarak ölçülmüştür. Cerrahlar ilk olarak, Kinesio bantlama uygulanmadan önce değerlendirilmiş, değerlendirmeler Kinesio bantlama uygulamasının 1 . ve 4 gününde tekrarlanmıştır.

BULGULAR: Bel ve boyun ağrısında anlamlı bir azalma gözlenmiştir ( $p<0.05)$. Oswestry Bel Özür Skalası ve Boyun Özür Skalası sonuçlarında da başlangıç skorları ile karşılaştııılığında istatistiksel olarak anlamlı azalma gözlenmiştir ( $p<0.05)$. Kinesio bantlama uygulamasından sonra hem boyun hem de bel eklem hareket açıklıklarında artış gözlenmiştir $(p<0.05)$.

SONUÇ: Kinesio bantlama bel ve boyun ağrısını azaltmada ve fonksiyonel performansı artırmada etkili bir yöntem olabilir. Bu teknik ameliyatlardan sonra iş kaynaklı kas iskelet sistemi problemleri yaşayan cerrahlarda kullanılabilir bir tekniktir.

ANAHTAR SÖZCÜKLER: Cerrahlar, Kas-iskelet sistemi ağrıları, Kinesio bantlama, Performans

\section{INTRODUCTION}

Work-related musculoskeletal disorders that affect a large number of employees every year (7) have been defined as a wide range of inflammatory and degenerative diseases and disorders affecting the tissues of the musculoskeletal system - tendons, muscles, ligaments, bones, nerves, and vascular structures. These conditions may affect the neck, shoulders, elbows, forearms, wrists and hands and may result in pain and functional impairment (7). Pain usually plays a major role in work-related musculoskeletal disorders. A limited range of motion is also a major symptom of these disorders (24). 
Surgeons are a unique group of healthcare professionals that are at risk for developing work-related musculoskeletal symptoms affecting their functional performance negatively (2). Surgeons' awkward body posture, increased muscle activity, repetitive movements of the upper extremities, and prolonged static head and back postures during surgical procedures are main problems, which cause work-related musculoskeletal disorders (1). Because of the position of the patient during open surgery, surgeons tend to lean forward and this results in increased extensor muscle activity to balance the body. In addition to these problems, surgeons also have to deal with problems related to inappropriate operating table height due to the different height of the surgeons in the surgical team (21).

Very few studies have examined musculoskeletal symptoms among physicians in various specialties. Liberman et al., who conducted a survey among over 600 colorectal surgeons, reported a high prevalence rate of injuries in the hands/ fingers, and the neck and back (15). Wauben et al. reported that over $80 \%$ of surgeons had experienced discomfort and pain in the neck, shoulders and back areas after surgery (25). Kant et al. conducted a study and reported that surgeons performed repeated static postures with forward bending of the head and twisting of the back. These positions were described as "distinctly harmful" by the subjects (13).

There are many preventive approaches and treatment options in the management of work-related musculoskeletal disorders. Some of these are exercise therapy (PNF, aerobic exercises, Feldenkrais therapy), behavioral training (cognitive training, relaxation training, a combination of cognitive and relaxation training), ergonomic approaches, massage, and manual therapy (23).

Kinesiotaping (KT) was developed about 25 years ago in Japan but in recent years it has been used as a special taping method in Turkey as in Europe and America. Kinesio tape, an alternative taping technique, has been theorized to improve a variety of physiological problems, including range of motion, based on the functions of the tape. KT has been theorized to be an effective treatment to restore muscle function and decrease pain (28).

There are also a few treatment and/or preventive modalities for such problems on doctors (1). Likewise, there are quite limited studies investigating the effect of Kinesiotape technique on work-related musculoskeletal disorders. The purpose of this study was to evaluate the effect of Kinesio tape technique on pain and functional performance of surgeons having musculoskeletal system pain after surgery.

\section{MATERIAL and METHODS}

\section{Participants}

Thirty- two surgeons between the ages of 27 and 44 yrs working in the General Surgery, Plastic Surgery, Cardiovascular Surgery, Pediatric Cardiovascular Surgery, Orthopaedics, Neurosurgery or Urology departments in a university hospital participated in this study. All surgeons were given consent forms and the study was approved by the Ankara Clinical Research Ethics Committee Number 3.

\section{Procedures}

Age, professional experience, workdays per week, average operative time per day, exercise habits, smoking and alcohol consumption habits, musculoskeletal system problems, operating room conditions and equipment satisfaction ratings were recorded in an assessment form. Surgeons were asked to identify body regions that they had experienced discomfort with in the past 12 months, based on demarcations of body regions in the Standardized Nordic Questionnaire (9).

All surgeons that participated the study were evaluated in terms of pain, range of motion and functional performance related to quality of life. The Visual Analog Scale (VAS) was used for neck and low back pain assessment. Oswestry Low Back and Neck Disability Indexes were used to determine the impact of pain on surgeons' daily living activities. $(22,26)$. A goniometer was used to measure the differences in range of motion before and after surgery. The cervical flexion, cervical extension, right/left cervical rotation and right/ left lateral flexion angles were measured to evaluate cervical region range of motion limitation. Similarly, lumbar flexion, extension and right/left lateral flexion angles were measured for the lumbar region. Surgeons were evaluated in the morning and evening. The first day, surgeons were evaluated without Kinesiotaping. They had sociodemographic assessment and pain assessment, range of motion measurement and Oswestry Low Back and Neck Disability Index assessments.

The day when there is similar work load, KT was applied on trapezius (Figure 1), rhomboideus (Figure 2 ) and sacrospinalis muscles (Figure 3) with KT's muscle technique according to neck or low back pain. For general back pain, Kinesiotape was applied as a $\mathrm{Y}$ tape starting from T12 (Figure 4). It was not removed for 4 days (14).

Range of motion measurements and pain evaluation were repeated on the first day of Kinesio taping application. All measurements were also repeated on the fourth day of tape application. However pain evaluation was done all four days with VAS.

\section{Statistical Analysis}

Statistical tests were performed using SPSS for Windows 14.0 (SPSS, Inc., Chicago, IL) to determine surgeons' defining characteristics. To compare alterations of surgeons' pain and range of motion between the days with or without KT, nonparametric analysis of longitudinal data with "LD_f1 design" was used (6). The differences of Oswestry Low Back and Neck Disability Index Scores were analyzed with MannWhitney $U$ test before and after KT application. Statistical significance was set at $\mathrm{p}=0.05$.

\section{RESULTS}

Descriptive findings of surgeons such as mean age, height, body weight, body mass index, professional experience, daily 


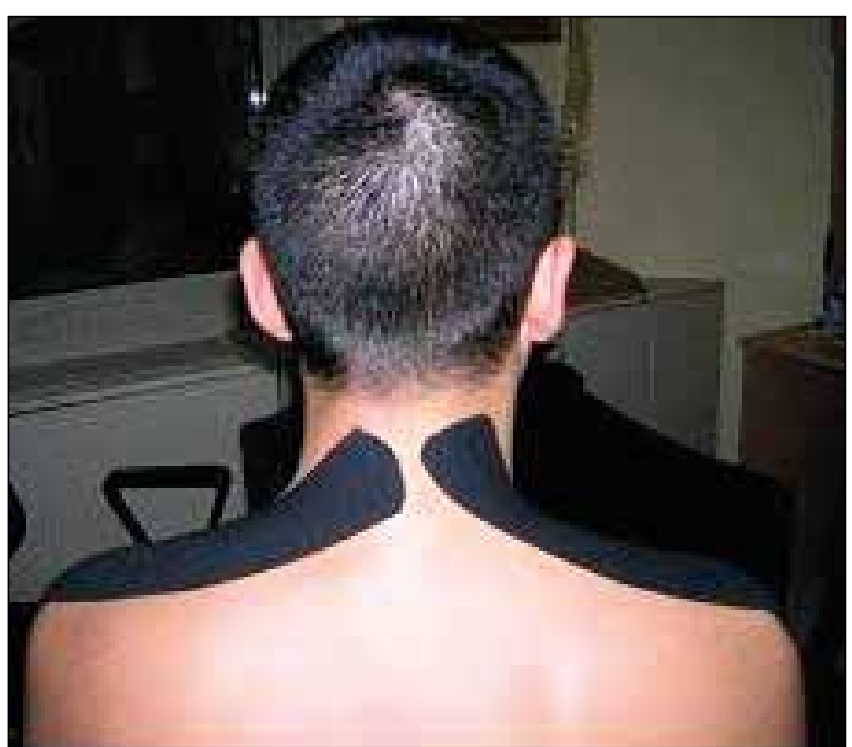

Figure 1: KT application on Trapezius muscle.

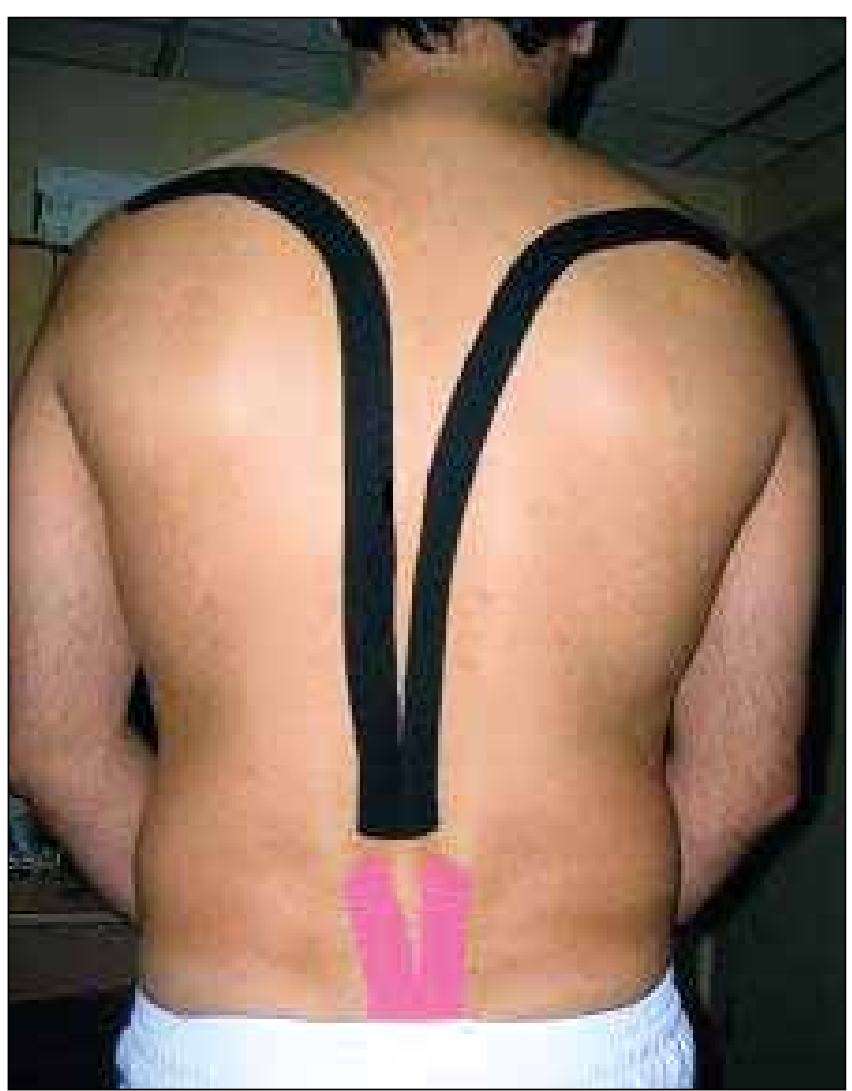

Figure 3: KT application for sacrospinal muscles.

working hours, daily and weekly operation time are given in Table I.

It was observed that only $37.5 \%$ of surgeons have an exercise habit. Surgeons reported experiencing musculoskeletal symptoms at least in one area in the past 12 months. The low back region had the highest prevalence rate of $25 \%(n=32)$,

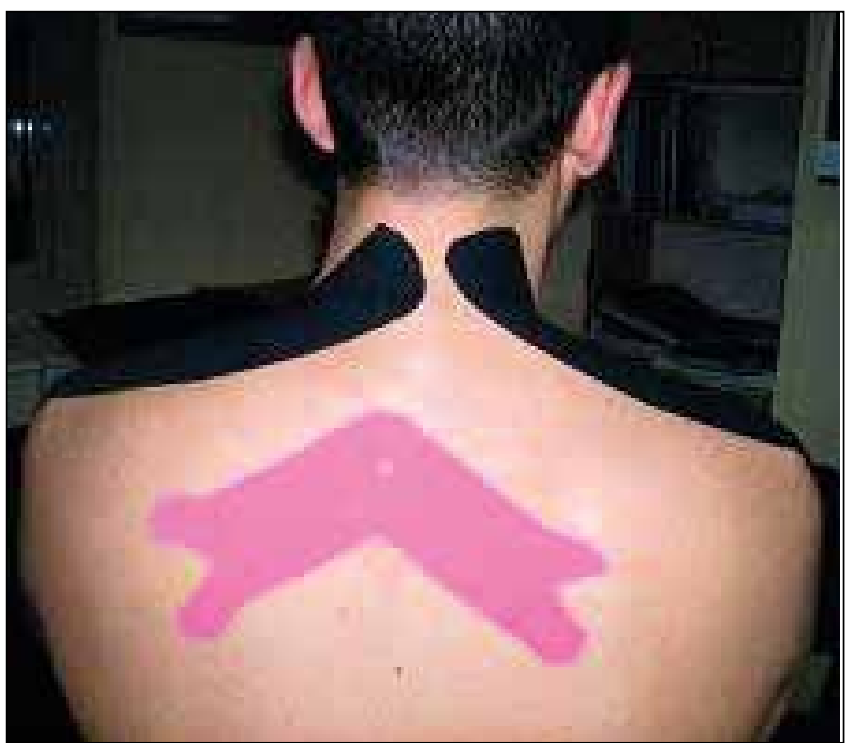

Figure 2: KT application on Upper Trapezius and Rhomboideus muscles.

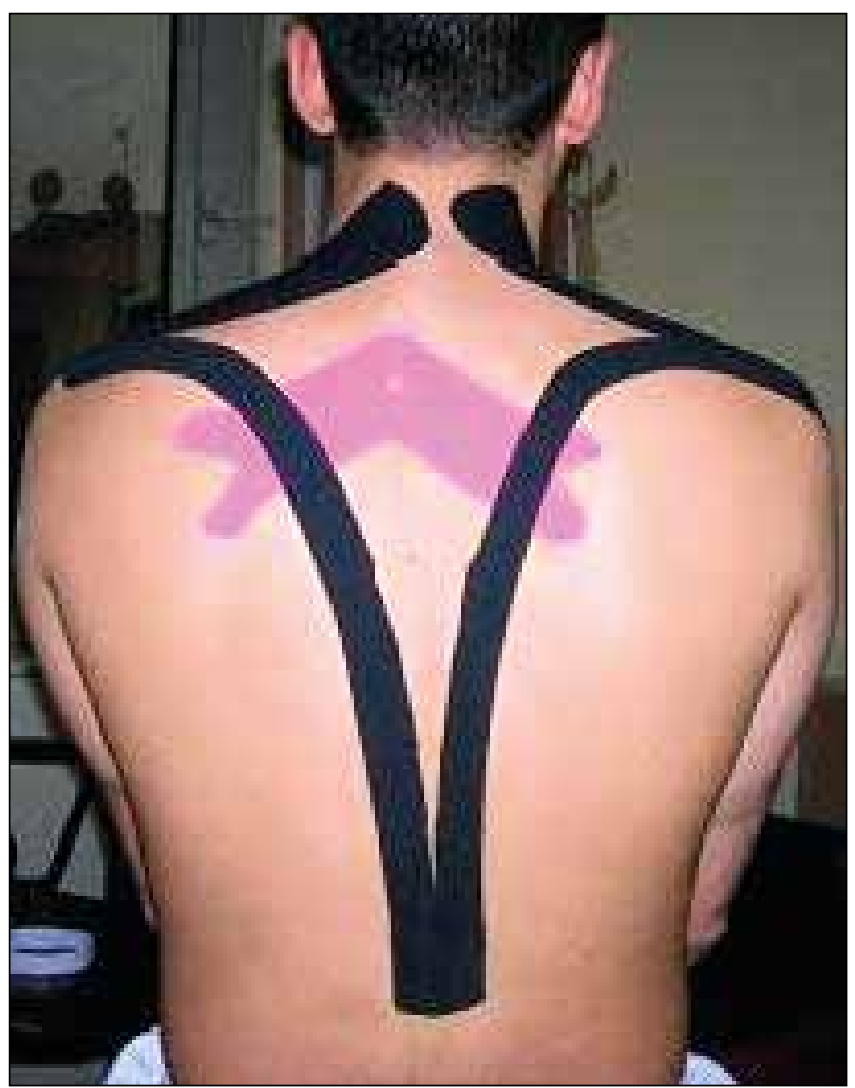

Figure 4: $Y$ tape for general back pain.

followed by the upper back with $24 \%$. Surgeons experienced musculoskeletal symptoms in the past 7 days too. The highest prevalence rate was in the neck region with $27 \%$ percent.

The Oswestry Low Back Disability Index score before treatment was $4.38 \pm 3.67$. Four day after KT application, the mean score became $2.77 \pm 2.76$. This reduction was statistically significant 
$(p<0.05)$. Similarly, the mean score of Neck Disability Index before treatment was $3.84 \pm 3.14$, while after treatment score was $2.52 \pm 2.54$. The Neck Disability Index mean score reduced significantly $(\mathrm{p}<0.05)$ (Table II).

Surgeons' cervical range of motion measurements recorded in the day without taping (zero day), first day and the fourth day of KT application were compared. When cervical range of motion was evaluated, the relative effects of cervical flexion angle on zero day was found as 0.35 (0.02 - 0.41), whereas $0.56(0.004-0.6)$ on the first day and $0.59(0.009-0.62)$ on the fourth day. The observed increase in cervical flexion angle was statistically significant $(p<0.05)$. Cervical extension angle relative effects of zero day were $0.39(0.01-0.44)$,) but 0.56 (0.005- 0.59) on the first day and 0.55 (0.008 - 0.59) on the fourth day. The observed increase in cervical extension angle was statistically significant $(p<0.05)$.

Cervical right lateral flexion angle relative effects of zero day were $0.32(0.01-0.37)$ whereas $0.56(0.01-0.6)$ on the first day, $0.6(0.01-0.64)$ on the fourth day. The observed increase in cervical right lateral flexion angle was statistically significant $(p<0.05)$. Cervical left lateral flexion angle relative effects of zero day was $0.34(0.02-0.39)$ whereas $0.56(0.0008-0.59)$ on the first day, $0.6(0.002-0.63)$ on the fourth day. The observed increase in cervical left lateral flexion angle was statistically significant $(p<0.05)$. Cervical right rotation angle relative effects of zero day was $0.39(0.02-0.43)$ whereas $0.55(0.006-$ $0.57)$ on the first day, $0.57(0.01-0.60)$ on the fourth day. The observed increase in cervical right rotation angle was statistically significant $(p<0.05)$. Cervical left rotation angle relative effects of zero day was found as $0.37(0.02-0.43)$ whereas $0.54(0.01-0.57)$ on the first day, $0.59(0.01-0.63)$ on the fourth day. The observed increase in cervical left rotation angle was statistically significant $(p<0.05)$.
Surgeons' lumbar range of motion measurements also recorded on the opening day, first day and the fourth day of KT application were compared. When lumbar range of motion was evaluated, lumbar flexion angle relative effects of zero day was found as $0.33(0.15-0.38)$ whereas $0.57(0.01-0.61)$ in the first day; $0.59(0.006-0.62)$ in the fourth day. The observed increase in lumbar flexion angle was statistically significant ( $p$ $<0.05)$. Lumbar extension angle relative effects of zero day was found as $0.38(0.01-0.43)$ whereas $0.55(0.001-0.58)$ in first day; $0.56(0.01-0.6)$ in fourth day. The observed increase in lumbar extension angle was statistically significant $(p<0.05)$.

Lumbar right lateral flexion angle relative effects of zero day was found as $0.38(0.02-0.39)$ whereas $0.5(0.01-0.54)$ in the first day, $0.61(0.02-0.66)$ in fourth day. The observed increase in lumbar right lateral flexion angle was statistically significant $(p<0.05)$.

Lumbar left lateral flexion angle relative effects of zero day was found as $0.38(0.02-0.43)$ whereas $0.49(0.007-0.52)$ in first day, 0.62 (0.002 - 0.66) in fourth day. The observed increase in lumbar left lateral flexion angle was statistically significant ( $p$ $<0.05)$.

Surgeons were evaluated with VAS to have an objective data about their neck and low back pain after surgery. Pain in the neck and lumbar region were evaluated on the day without tape then after Kinesio tape application, pain score alterations were viewed for four days. Then the results were compared.

Neck pain relative effects of zero day was recorded as 0.66 (0.04- 0.73) whereas, $0.56(0.02-0.6)$ in first day, 0.46 (0.01- 0.5) in second day, $0.36(0.03-0.43)$ in third day and finally 0.43 (0.02-0.49) in fourth day (Figure 5).

Low back pain relative effects of zero day was recorded as $0.66(0.04-0.71)$ whereas, $0.57(0.01-0.61)$ in first day, 0.50

Table I: Demographic Characteristics of Surgeons

\begin{tabular}{|l|c|c|c|c|c|}
\hline Parameters & mean & Std. Dev. & Median & Min-max & N \\
\hline Age (year) & 32.13 & 5.74 & 32.37 & $26-52$ & 32 \\
\hline Height (cm) & 175.86 & 5.63 & 178 & $158-185$ & 32 \\
\hline Body weight (kg) & 78.72 & 12.87 & 79.5 & $51-106$ & 32 \\
\hline Body mass index (VKi) (kg/m ${ }^{2)}$ & 25.27 & 3.51 & 24.97 & $18.04-33.08$ & 32 \\
\hline Professional experience (year) & 7.03 & 6.00 & 5 & $1-28$ & 32 \\
\hline Working hour daily & 10.07 & 0.37 & 6 & $6-7$ & 32 \\
\hline Operation time daily & 5.03 & 1.66 & 4.5 & $2-9$ & 32 \\
\hline Operation time weekly & 21.53 & 7.86 & 20 & $10-48$ & 32
\end{tabular}

Table II: Changes in Oswestry Low Back Disabilitiy Index and Neck Disability Index Scores

\begin{tabular}{|l|l|c|r|r|r|}
\hline & Mean & Std. dvtn & $\min$-max & $\mathbf{n}$ \\
\hline \multirow{3}{*}{ Oswestry low back disability index } & Before KT application & 4.38 & 3.67 & $0-15$ & 32 \\
& After KT application & 2.77 & 2.76 & $0-10$ & 32 \\
Neck disability index & Before KT application & 3.84 & 3.14 & $0-10$ & 32 \\
& After KT application & 2.52 & 2.54 & $0-8$ & 32 \\
\hline
\end{tabular}


(0.01- 0.54) in second day, $0.47(0.02-0.52)$ in third day and finally 0.28 (0.03- 0.35) in fourth day (Figure 6).

\section{DISCUSSION}

The most influential factor leading to surgeons' musculoskeletal problems during the operation is static and improper posture (88.9\%). Muscle fatigue (44.4\%) and repetitive movements (37.8\%) also lead to musculoskeletal problems (2). In a study it was demonstrated that static postures are supposed to be as back pain triggers (4).

Szeto et al examined work-related musculoskeletal disorders among surgeons, they found more than $80 \%$ of the participants experienced at least one musculoskeletal problem in the last 12 months. In the same study, it was shownthat the most affected region was the neck with $82.9 \%$, while the waist with $68.1 \%$, the shoulder with $57.8 \%$, followed by the thoracic region with $52.6 \%(21)$. In another study, it was reported that after an open surgery, 30\% of surgeons felt shoulder, neck and low back pain and tension. (17). In our study, surgeons reported experiencing musculoskeletal symptoms in at least one area in the past 12 months. The low back region had the highest prevalence rate of $25 \%(n=32)$, followed by the upper back with $24 \%$. Surgeons experienced musculoskeletal symptoms in the past 7 days too. The highest prevalence rate was in the neck region with $27 \%$. Looking at the daily changes in the neck and low back pain in our study, the group having the greatest pain scores was General Surgeons. Compared to other surgical departments, general surgery operations take a lot longer (45.1\%). Therefore, it can be said that the general surgeons who stay longer at a fixed position would feel more pain than other surgical groups.

In one study, designed ergonomic body support for surgeons has been tested during seven surgical procedures. Back and leg muscles were evaluated by electromyography while being supported. EMG results showed that the body supports effectively reduce the muscle activity. With the chest support, erector spinalis muscle activity reduction was observed at a rate of $44 \%$. Semitendinosus and gastrocnemius muscle activity reduction was seen at rates of $20 \%$ and $74 \%$ respectively. According to this study, body supports are recommended to be used in order to reduce muscle activity so physical problems and diseases may be reduced in the long term. With this support the surgeon can work in his/ her natural posture (1). Various treatment modalities, and ergonomic approaches are thought to be the most effective treatments for work-related musculoskeletal disorders but, however they are still not fully proven. Whether exercise is protective for work-related musculoskeletal disorders is not yet fully supported in randomized controlled trials (27).

Kinesiotape creates pressure on the skin and stretches the skin. By stimulating cutaneous mechanoreceptors, this external loading causes physiological changes in the region where KT was applied. KT increases the distance between skin and muscle and interstitial fluid by increasing the blood and lymphatic circulation (28). The number of studies with

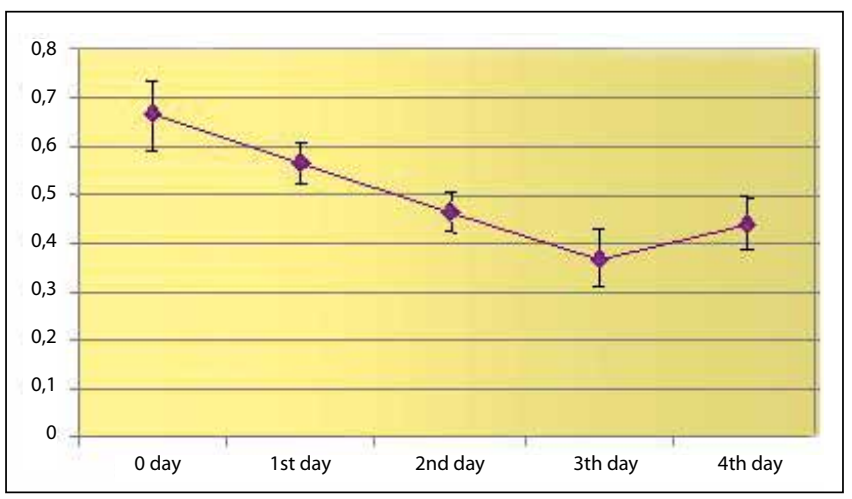

Figure 5: Daily changes of neck pain (VAS scores).

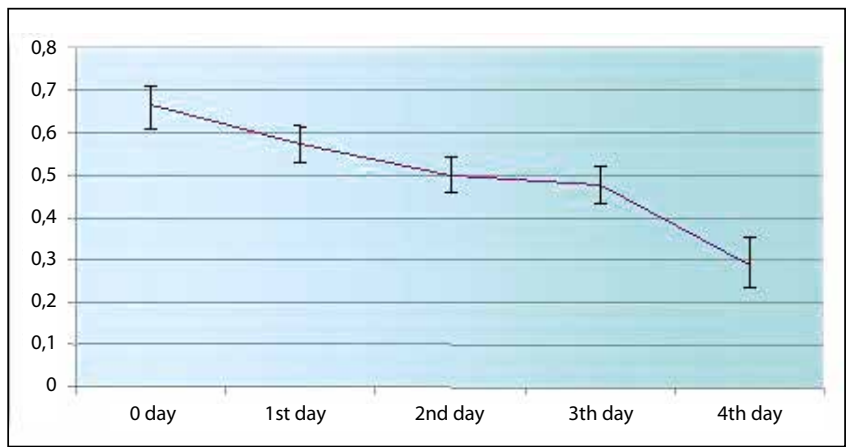

Figure 6: Daily changes of low back pain (VAS scores).

Kinesiotape is very limited in the literature (1). Ayako Yoshida examined the effects of KT on trunk flexion, extension and lateral flexion in 30 healthy subjects. As a result of this study, it was found that KT had an effect on active flexion of the lower body by increasing the width of range of motion, however did not have any significant effect on lumbar extension and lateral flexion (28). In our study, we investigated the effect of Kinesiotaping on lumbar flexion, extension and lateral flexion range of motion in surgeons after surgery. As a result of taping, not only lumbar flexion but also lumbar extension and lateral flexion range of motion were increased.

Bishop et al examined the impact of KT on 37 patients with low back pain in a randomized controlled study. A visual analogue scale was used for pain assessment. Daily activity restrictions associated with low back pain were assessed by the Oswestry Low Back Disability Index. Looking at the results of pain, both control group and KT group showed a significant reduction but no significant difference between the two groups was observed. In terms of the results of the Oswestry Low Back Disability Index, significant decrease was observed in only KT group (5).

In this study, surgeons' low back and neck pain influence on functional performance was assessed with the Oswestry Low Back and Neck Disability Index. According to the results of the Oswestry Low Back Index, after KT treatment, low back pain decreased $36.75 \%$ compared to before treatment. Similarly according to the Neck Disability Index, neck pain was decreased $34.37 \%$ compared to initial status. The mean 
scores'reduction were statistically significant. Looking at these results, it can be said that Kineosiotape has an enhancing effect on the functional performance of surgeons. According to the effect of KT on low back pain, the most significant decline of low back pain was observed on the fourth day of KT application. That can be explained as a physiological effect of KT which is normally seen 72 hours after taping application.

In our study, the effect of KT on cervical spine range of motion was investigated. After application of $\mathrm{KT}$, cervical flexion, cervical extension, cervical right / left lateral flexion, cervical right / left rotation range of motions showed a significant increase.

When we look at the effects of KT on neck pain, we can see a reduction in pain after tape application. The study supports the literature as the most significant decrease in neck pain was observed on the second day of KT application. In our study, the most effective reduction in neck pain of surgeons was observed on the second day, whereas the most effective low back pain reduction was on the fourth day. As the cause of this difference it can be said that there is less subcutaneous fat layer in the neck region than lumbar region so KT may have a faster effect on neck region.

It is indicated that after prolonged static posture, when surgeons want to move again, they feel too much pain and retention. Surgeons who participated in this study, indicated that when they compared the tapeless day with taped days, after KT application they felt that they have an invisible support on the back moving invisible load. They also indicated that after KT application they felt very relaxed. Although the study was concluded, before long time operations, they want KT application even now. This shows us that KT has an psychological effect as well as the physiological effects in surgeons. Because of intense pace of work, surgeons do not have exercise habit. Only $37.5 \%$ surgeons participated in the study had regular exercise habit. Surgeons could not find time for exercise. Kinesiotape is a new treatment option for surgeons that do not have much time to relax.

The lack of a control group is one of the limitations of the study. If KT group is compared with an exercise training group or a control group, it may give more accurate results about the effects of KT. In this study, acute effects of KT in surgeons were investigated. This is also a limitation. Further studies are needed to see long term effects of KT on surgeons' workrelated musculoskeletal pain.

In conclusion, findings demonstrated that Kinesiotaping would be an effective method for reducing neck and low back pain and improving cervical and lumbar range of motions and functional performance. This technique can be used for surgeons who have work-related musculoskeletal symptoms after performing surgery.

\section{REFERENCES}

1. Albayrak A, Van Veelen MA, Prins JF, Snijders CJ, De Ridder H, Kazemier G: A newly designed ergonomic body support for surgeons. Surgical Endoscopy 21:1835-1840, 2007

2. Bernard BP: A critical review of epidemiologic evidence for work-related musculoskeletal disorders of the neck, upper extremity, and low back, Department of Health and Human Services. In: Musculoskeletal Disorders (Msds) And Workplace Factors. National Institute of Occupational Safety and Health Publication 1997: 97-141

3. Barbe MF, Barr AE: Inflammation and the pathophysiology of work-related musculoskeletal disorders. Brain, Behavior, and Immunity 20: 423-429, 2006

4. Berguer R: Surgery and ergonomics. Archives of Surgery 134:1011-1016, 1999

5. Bishop B: Use of Kinesio taping method on lower back pain: Randomized controlled clinical trial. KTA International Symposium, Rome, 2010

6. Brunner E, Domhof S, Langer F: Nonparametric Analysis of Longitudinal Data In Factorial Experiments. Wiley Series in Probability and Statistics, 2002

7. Buckle PW, Devereux JJ: The nature of work-related neck and upper limb musculoskeletal disorders. Applied Ergonomics 33: 207-217, 2002

8. Bureau of Labor Statistics: Lost-work time injuries and illnesses: characteristics and resulting days away from work. United States Department Of Labor News USDL 05-521, March 302003

9. Crawford JO: The Nordic musculoskeletal questionnaire. Occupational Medicine 57(4): 300-301, 2007

10. Copstead LE, Banadki JL: Pathophysiology: Biological and Behavioral Perspectives. Philadelphia: W.B. Saunders, 2000

11. Dawson AP, Mclennan SN, Schiller SD, Jull GA, Hodges PW, Stewart S: Interventions to prevent back pain and back injury in nurses: Systematic review. Occupational and Environmental Medicine 64: 642-650, 2007

12. Hangberg M, Harms-Ringdahl K, Nisell R, Wigeus Hjelm E: Isometric shoulder endurance training compared to isometric shoulder strength training in rehabilitation of female industrial workers with neck-shoulder pain: A randomised controlled trial. Helsinki: Abstract Book, PREMUS-ISEOH '98 3rd International Conference On Prevention Of Work-Related Musculoskeletal Disorders 29, 1998

13. Kant I, Jong LC, Van Rijssen-Moll M, Borm PJ: A survey of static and dynamic work postures of operating room staff. Int Arch Occup Environ Health 63: 423-428, 1999

14. Kase K, Wallis J, Kase T Clinical Therapeutic Applications of the Kinesiotaping Method. Tokyo: 2003

15. Liberman AS, Shrier I, Gordon PH: Injuries sustained by colorectal surgeons performing colonoscopy. Surgical Endoscopy 19: 1606-1609, 2005

16. Lindman R, Hagberg M, Angqvist KA, Söderlund K, Hultman E, Thornell LE: Changes in muscle morphology in chronic Trapezius Myalgia. Scand J Work Environ Health 17:347-355, 1991 
17. Mirbod SM, Yoshida H, Miyamoto K, Miyashita K, Inaba R, Iwata $\mathrm{H}$ : Subjective complaints in orthopaedists and general surgeons. Int Arch Occup Environ Health 67:179-186, 1995

18. Rempel DM, Krause N, Goldberg R, Benner D, Hudes M, Goldner GU: A randomised controlled trial evaluating the effects of two workstation interventions on upper body pain and incident musculoskeletal disorders among computer operators. Occupational and Environmental Medicine 63(5): 300-306, 2006

19. Sertoğlu E: Patellofemoral Ağrı Sendromlu Hastalarda Kinezyoteyp Uygulamasının Tedavi Etkinliğinin İncelenmesi. Yüksek Lisans Tezi, Hacettepe Üniversitesi, Ankara 2008

20. Sjogren T, Nissinen KJ, Jarvenpaa SK, Ojanen MT, Vanharanta $H$, Mälkiä EA: Effects of a workplace physical exercise intervention on the intensity of headache and neck and shoulder symptoms and upper extremity muscular strength of office workers: A cluster randomized controlled cross-over trial. Pain 116(1-2): 119-128, 2005

21. Szeto GP, Ho P, Ting AC, Poon JT, Cheng SW, Tsang RC: Workrelated musculoskeletal symptoms in surgeons. J Occup Rehabil 19:175-184, 2009
22. Telci EA, Karaduman A, Yakut Y, Aras B, Simsek IE, Yagli N: The cultural adaptation, reliability and validity of neck disability index in patients with neck pain: A Turkish version study. Spine 34 (16): 1732-1735, 2009

23. Verhagen AP, Karels C, Bierma-Zeinstra SM, Feleus A, Dahaghin S, Burdorf A, Koes BW: Exercise proves effective in a systematic review of work-related complaints of the arm, neck, or shoulder. J Clin Epidemiol 60: 110-117, 2007

24. Nielson WR, Macdermid JC: Preliminary evaluation of the Generalized Work Distress Scale in patients with work-related upper extremity disorders. J Occup Rehabil 15 (1): 3-16, 2005.

25. Wauben LS, Van Veelen MA, Gossot D, Goossens RH: Application of ergonomic guidelines during minimally invasive surgery: A questionnaire survey of 284 surgeons. Surgical Endoscopy 20:1268-1274, 2006

26. Yakut E, Düger T, Oksüz C, Yörükan S, Ureten K, Turan D, Frat T, Kiraz S, Krd N, Kayhan H, Yakut Y, Güler C: Validation of the Turkish version of the Oswetry Disability Index for patients with low back pain. Spine 29 (5):581-585, 2004

27. Yassi A: Repetitive strain injuries. Lancet 349: 943-947, 1997

28. Yoshida A, Kahanov L: The effect of kinesio taping on lower trunk range of motions. Sports Medicine 15: 103-112, 2007 